\title{
Production, Capital Stock, and Price Level Dynamics in the Light of Kaldorian Model $^{\#}$
}

\author{
Jan Kodera - Miloslav Vošvrda*
}

\section{Production Sector and Capital Formation Model - A Statement}

The Kaldor model has became a kernel of nonlinear models of closed economy. The description of basic principles of Kaldor theory is in books Allen R.D.G. (1967) or in Tobin (1975). There are descriptions of the Kaldor model in many textbooks for the economic dynamics. For example we can take it in Lorenz (1994) or Medio (1992). The similar form of the Kaldor model is analysed by Flaschel, Franke, and Semmler (1997). Further modifications and extensions of Kaldor model we can find in Kodera (2002), Kodera, Sladký and Vošvrda (2003a or 2003b). A traditional form of this model has the following form

$$
\dot{Y}=\alpha[I(Y, K)-S(Y)]
$$

where $Y, K$ depend on time and stand for a production and a capital stock respectively. The parameter $\alpha>0$ is the adjustment parameter. Investments $I$ are increasing in the $Y$ and are decreasing in the $K$. The savings $S$ are an increasing function of $Y$. The equation (1) describes a production dynamics which is expressed as a consequence of disequilibrium between investments and savings. The capital increase $\dot{K}$ is equal to the difference of investment and capital consumption. The capital consumption is assumed to be an increasing function of capital stocks $D(K)$. The equation expressing capital dynamics is in the form as follows

$$
\dot{K}=I(Y, K)-D(K) \text {. }
$$

The investment function is supposed to be the product of propensity to invest $j(\chi)$ depending on an expected productivity of capital $\chi$ and a production $Y$. As we assume that the individuals expect the actual productivity of capital we have

$$
\chi=\frac{Y}{K} \text {. }
$$

\footnotetext{
The support from the Czech Science Foundation under the grant 402/06/0990, from the Ministry of Education of the Czech Republic under project MSM0021620841, and from The Centre for Dynamic Economics and Econometrics is gratefully acknowledged.

Prof. RNDr. Ing. Jan Kodera, CSc. - professor; Department of Monetary Policy and Theory, Faculty of Finance and Accounting, University of Economics, Prague, nám. W. Churchilla 4, 13067 Prague 3, Czech Republic; $<$ kodera@vse.cz>.

Doc. Ing. Miloslav Vošvrda, CSc. - head of Department of Econometrics, Institute of Information Theory and Automation, the Academy of Sciences of the Czech Republic, Pod Vodárenskou věží 4, 18208 Prague 8, Czech Republic; <vosvrda@utia.cas.cz>.
} 
From the equation (3) we can obtain $\varepsilon=\ln \chi=y-k$, where $y, k$ stand for $y=\ln Y$, $k=\ln K$ respectively. For the investment function we assume

$$
I(Y, K)=j(\chi) \cdot Y=j(Y / K) \cdot Y .
$$

Using this notation we get

$$
j(Y / K)=j\left(e^{\varepsilon}\right)=j\left(e^{y-k}\right) .
$$

A propensity to invest $j$ is an increasing function of $\varepsilon$ and it is assumed that it approaches to zero for decreasing $\varepsilon$ to minus infinity and approaches to the maximum level for increasing $\varepsilon$. We use a logistic function $\lambda(\cdot)$ to express the propensity to invest. We assume that $\mu \cdot \lambda(\varepsilon), \mu>0$ is good approximation of the propensity to invest. The logistic function $\lambda(\varepsilon)$ is a solution of the following differential equation

$$
\frac{d \lambda(\varepsilon)}{d \varepsilon}=\lambda(\varepsilon) \cdot(a-b \cdot \lambda(\varepsilon))
$$

Let us consider an initial condition $\lambda(0)=\lambda_{0}$. Then the logistic function $\lambda($.$) takes$ on the following form

$$
\lambda(\varepsilon)=\frac{a \cdot \lambda_{0}}{\left.b \cdot \lambda_{0}+\left(a-b \cdot \lambda_{0}\right)\right) \cdot e^{-a \cdot \varepsilon}} . \quad a>0, \quad b>0 .
$$

We receive the propensity to invest $i$ in the following form

$$
i(\varepsilon)=\mu \cdot \lambda(\varepsilon)=\frac{a \cdot \mu \cdot \lambda_{0}}{b \cdot \lambda_{0}+\left(a-b \cdot \lambda_{0}\right) \cdot e^{-a \cdot \varepsilon}},
$$

or

$$
i(y-k)=\mu \cdot \lambda(y-k)=\frac{a \cdot \mu \cdot \lambda_{0}}{b \cdot \lambda_{0}+\left(a-b \cdot \lambda_{0}\right) \cdot e^{-a \cdot(y-k)}} .
$$

For a saving function we have used the following expression

$$
S(Y)=\left(s_{0}+s_{1} \cdot y-s_{2} \cdot \pi^{e}\right) \cdot Y \text {. }
$$

The above equation describes the dependence of savings on investments as the product of a production $Y$ and propensity to save $s_{0}+s_{1} \cdot y-s_{2} \cdot \pi^{e}$ which is not a constant. We assume that it depends on a production $y$ and on an expected inflation $\pi^{e}$. The dependence on the $y$ is positive, the dependence on the expected inflation $\pi^{e}$ is a negative. The higher expected inflation $\pi^{e}$ the higher reduction of savings $S(Y)$. Let us rearrange the equation (1) using the expressions for investments and savings. We get

$$
\dot{Y}=\alpha \cdot\left[i(y-k) \cdot Y-\left(s_{0}+s_{1} \cdot y-s_{2} \cdot \pi^{e}\right) \cdot Y\right] .
$$

Dividing the equation (11) by $Y$, we get

$$
\dot{y}=\alpha \cdot\left[i(y-k)-\left(s_{0}+s_{1} \cdot y-s_{2} \cdot \pi^{e}\right)\right] \text {. }
$$


Let $D=\beta \cdot K^{\gamma}$, and $\beta, \gamma \in(0,1)$ denotes a capital consumption expressing the depreciated portion of the capital. A capital formation in the closed economy is described by the following differential equation

$$
\dot{K}=I(Y, K)-\beta \cdot K^{\gamma},
$$

or by the following one

$$
\dot{K}=i(y-k) \cdot Y-\beta \cdot K^{\gamma} \text {. }
$$

Dividing the equation (14) by $K$ we get

$$
\frac{\dot{K}}{K}=i(y-k) \cdot \frac{Y}{K}-\beta \cdot K^{\gamma-1} \text {. }
$$

Using logarithms instead of original values of $Y$ and $K$ we get

$$
\dot{k}=i(y-k) \cdot e^{y-k}-\beta \cdot e^{(\gamma-1) \cdot k} .
$$

The equations (12) and (16) describe the production dynamics and the capital formation dynamics, i.e. the dynamics of Kaldor model. The final forms of these equations are as follows

$$
\begin{aligned}
& \dot{y}=\alpha\left[\frac{a \cdot \mu \cdot \lambda_{0}}{b \cdot \lambda_{0}+\left(a-b \cdot \lambda_{0}\right) e^{-a(y-k)}} \cdot\left(s_{0}+s_{1} y-s_{2} \cdot \pi^{e}\right)\right], \\
& \dot{k}=\frac{a \cdot \mu \cdot \lambda_{0}}{b \cdot \lambda_{0}+\left(a-b \cdot \lambda_{0}\right) \cdot e^{-a(y-k)}} \cdot e^{y-k}-\beta \cdot e^{(\gamma-1) k} .
\end{aligned}
$$

\section{Price Level and Expected Inflation Dynamics}

Let us add to the considered model the equations for a price level dynamics and an expected inflation dynamics. Price level dynamics outflows from a disequilibrium in money market. Demand for money in the money market is assumed to be given by Fisherian demand for the money equation

$$
M^{d}=\frac{1}{V\left(\pi^{e}\right)} P \cdot Y,
$$

where $M^{d}$ - demand for money, $P$ - the price level, $V$ - the velocity of money, $\pi^{e}-$ the expected inflation. A velocity of money $V$ is assumed to increase with an expected inflation $\pi^{e}$. Making the logarithm of the above equation we get

$$
m^{d}=p+y-v\left(\pi^{e}\right),
$$

where $m^{d}$ - logarithm of demand for money, $p$ - logarithm of price level, $v$ - logarithm of the velocity of money. A logarithm of the velocity of money is assumed to be given by the following equation

$$
v\left(\pi^{e}\right)=v_{0}+\kappa \cdot \theta\left(\pi^{e}\right),
$$

where a constant $v_{0}$ is determined by a technological level of the banking sector. A parameter $\kappa$ is a constant and $\theta$ is a logistic function solving the logistic equation 


$$
\frac{\mathrm{d} \theta(\pi)}{\mathrm{d} \pi}=\theta(\pi) \cdot(g-h \cdot \theta(\pi)) .
$$

Supplying an initial condition $\theta(0)=\theta_{0}$ we get particular solution of the above differential equation

$$
\theta\left(\pi^{e}\right)=\frac{g \cdot \theta_{0}}{h \cdot \theta_{0}+\left(g-h \cdot \theta_{0}\right) \cdot e^{-g \cdot \pi^{e}}} .
$$

Now we are ready to introduce an equation for the price level dynamics in the extended model. The price level dynamics is a consequence of the disequilibrium in money market. An equilibrium is expressed by the difference between supply of money $m^{s}$ and demand for money $m^{d}$, so we get

$$
\dot{p}=\sigma \cdot\left(m^{s}-m^{d}\right),
$$

where $\sigma$ is an adjustment parameter. Replacing $m^{d}$ from (20) and using (21), (24) yields

$$
\dot{p}=\sigma \cdot\left[m^{s}-p-y+v_{0}+\kappa \cdot \theta\left(\pi^{e}\right)\right] .
$$

An adaptive expectation of inflation is expressed by

$$
\dot{\pi}^{e}=\omega \cdot\left(\dot{p}-\pi^{e}\right)
$$

Substituting from (25) to (26) we get

$$
\dot{\pi}^{e}=\omega \cdot\left\{\sigma \cdot\left[m^{s}-p-y+v_{0}+\kappa \cdot \theta\left(\pi^{e}\right)\right]-\pi^{e}\right\} .
$$

Using the relation (21) we get the final form of the equations describing the price level dynamics and the adaptive expectation of inflation:

$$
\begin{aligned}
& \dot{p}=\sigma \cdot\left(m^{s}-y-p+v_{0}+\kappa \frac{g \cdot \theta_{0}}{h \cdot \theta_{0}+\left(g-h \theta_{0}\right) \cdot e^{-g \cdot \pi^{e}}}\right), \\
& \dot{\pi}^{e}=\omega \cdot\left[\sigma \cdot\left(m^{s}-y-p+v_{0}+\kappa \frac{g \cdot \theta_{0}}{h \cdot \theta_{0}+\left(g-h \cdot \theta_{0}\right) \cdot e^{-g \cdot \pi^{e}}}\right)-\pi^{e}\right] .
\end{aligned}
$$

This system is, in the final form, composed by equations (17), (18), (28), and (29). It exhibits a non-linear dynamical system. Such systems are very complex and their analysis requires comprehensive knowledge of the theory of differential equations. Basic information on the theory of dynamical systems and its application in economic dynamics we find in Takayama (1994). More detailed information and comprehensive theory is presented in Guckenhaimer and Holmes (1986).

In this article we focus on the analysis of stability and some numerical experiments and the computation of Lyapunov exponents. The Jacobian of this system has the following form 


$$
\begin{aligned}
& \mathbf{A}=\left\|\begin{array}{lccc}
\mathbf{A}_{11} & \mathbf{A}_{12} & \alpha s_{2} & 0 \\
\mathbf{A}_{21} & \mathbf{A}_{22} & 0 & 0 \\
-\omega \sigma & 0 & \mathbf{A}_{33} & -\omega \sigma \\
-\sigma & 0 & \mathbf{A}_{43} & -\sigma
\end{array}\right\| \\
& \mathbf{A}_{11}=\frac{\alpha a^{2} \mu \lambda_{0}\left(a-b \lambda_{0}\right) \exp (-a(y-k))}{\left[b \lambda_{0}+\left(a-b \lambda_{0}\right) \exp (-a(y-k))\right]^{2}}-s 1, \quad \mathbf{A}_{12}=\frac{-\alpha a^{2} \mu \lambda_{0}\left(a-b \lambda_{0}\right) \exp (-a(y-k))}{\left[b \lambda_{0}+\left(a-b \lambda_{0}\right) \exp (-a(y-k))\right]^{2}}, \\
& \mathbf{A}_{21}=\frac{a \mu \lambda_{0} \exp (y-k)}{b \lambda_{0}+\left(a-b \lambda_{0}\right) \exp (-a(y-k))}+\frac{a^{2} \mu \lambda_{0} \exp (y-k)\left(a-b \lambda_{0}\right) \exp (-a(y-k))}{\left(b \lambda_{0}+\left(a-b \lambda_{0}\right) \exp (-a(y-k))\right)^{2}} \\
& \mathbf{A}_{22}=-\frac{a \mu \lambda_{0} \exp (y-k)}{b \lambda_{0}+\left(a-b \lambda_{0}\right) \exp (-a(y-k))}-\frac{a^{2} \mu \lambda_{0} \exp (y-k)\left(a-b \lambda_{0}\right) \exp (-a(y-k))}{\left(b \lambda_{0}+\left(a-b \lambda_{0}\right) \exp (-a(y-k))\right)^{2}}, \\
& \mathbf{A}_{33}=\frac{\omega \sigma \kappa g^{2} \theta_{0}\left(g-h \theta_{0}\right) \exp (-g \pi)}{\left(h \theta_{0}+\left(g-h \theta_{0}\right) \exp (-g \pi)\right)^{2}}-1, \quad \mathbf{A}_{43}=\frac{\sigma \kappa g^{2} \theta_{0}\left(g-h \theta_{0} \exp (-g \pi)\right)}{\left(h \theta_{0}+\left(g-h \theta_{0}\right) \exp (-g \pi)\right)^{2}} . \\
& {\left[\begin{array}{l}
-0.4691609287+0.5176177832 \mathrm{I} \\
-0.001662483586 \\
-1.314033061 \\
-0.4691609287-0.5176177832 \mathrm{I}
\end{array}\right]}
\end{aligned}
$$

\section{Numerical Example of the Extended Model}

Let us calibrate the model by numbers in accordance with the following table

Table 1

\begin{tabular}{|c|c|c|c|c|c|c|c|c|c|c|c|c|c|c|c|c|c|}
\hline $\boldsymbol{a}$ & $\boldsymbol{b}$ & $\boldsymbol{\lambda}_{0}$ & $\boldsymbol{s}_{\mathbf{0}}$ & $\boldsymbol{s}_{\mathbf{1}}$ & $\boldsymbol{s}_{\mathbf{2}}$ & $\boldsymbol{\alpha}$ & $\boldsymbol{\beta}$ & $\boldsymbol{\gamma}$ & $\boldsymbol{\sigma}$ & $\boldsymbol{\omega}$ & $\boldsymbol{\mu}$ & $\boldsymbol{g}$ & $\boldsymbol{h}$ & $\theta_{0}$ & $\boldsymbol{\kappa}$ & $\boldsymbol{v}_{\mathbf{0}}$ & $\boldsymbol{m}^{\boldsymbol{s}}$ \\
\hline 1 & 1 & 0.5 & 0.2 & 0.05 & 0 & 35 & 0.1 & 1 & 0.6 & 0.8 & 0.25 & 1 & 1 & 0.5 & 15 & 1 & 2 \\
\hline
\end{tabular}

The propensity to invest and the propensity to save expressed by the equations (9) and (10) respectively have after the calibration the following form

$$
i(y-k)=\frac{0.25}{1+e^{-y+k}}, s=0.2+0.05 y .
$$

Using them in the equations (12) and (16) we get a numerical form of equations for a simulation of the simple model of the closed economy: 


\section{Production Dynamics}

$$
\dot{y}=35 \cdot\left[\frac{0.25}{1+e^{-y+k}}-(0.2+0.05 y)\right] \text {. }
$$

\section{Capital Formation Dynamics}

$$
\dot{k}=\frac{0.25}{1+e^{-y+k}} e^{y-k}-0.1 \text {. }
$$

Price Dynamics

$$
\dot{p}=0.6\left(2-y-p+1+\frac{0.75}{1+e^{-\pi^{e}}}\right) .
$$

\section{Adaptive Expected Inflation}

$$
\dot{\pi}^{e}=0.8\left[0.6\left(2-y-p+1+\frac{7.5}{1+e^{-\pi^{e}}}\right)-\pi^{e}\right] .
$$

The initial conditions were chosen as $y(0)=3, k(0)=10, p(0)=1$, and $\pi e(0)=0$. The trajectories of the numerical example are shown in Figure 1. Parameters are by Table 1.

Figure 1: Kaldorian Four Equations Model I.

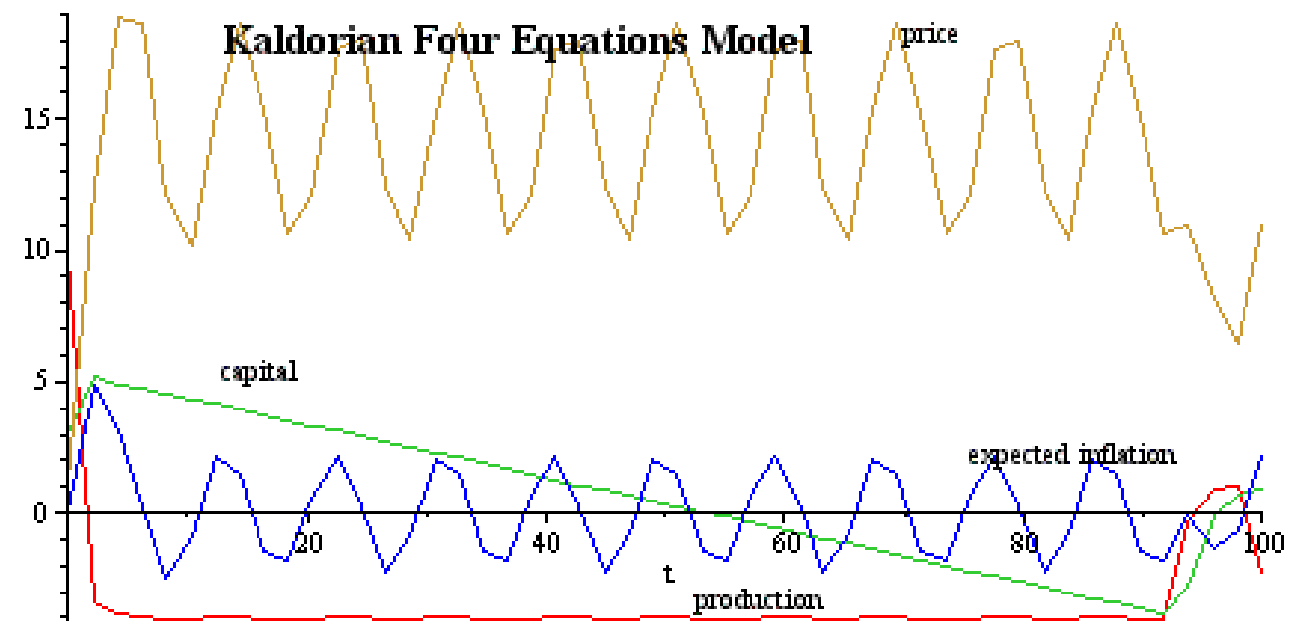


The scene (production, capital, price) of phase portrait is demonstrated in Figure 2, the scene (production, capital, expected inflation) is demonstrated in Figure 3, the scene (production, price, expected inflation) is demonstrated in Figure 4.

Figure 2: Kaldorian Four Equations Model IV.

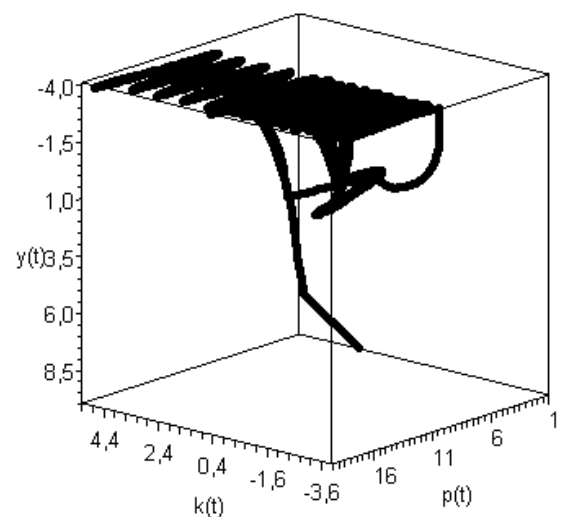

Figure 3: Kaldorian Four Equations Model V.

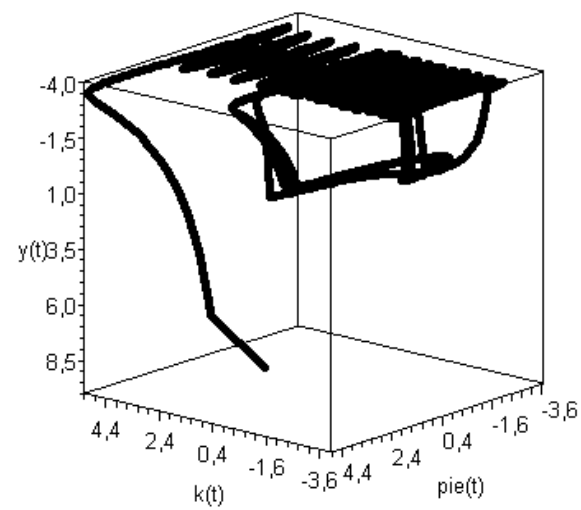

Figure 4: Kaldorian Four Equations Model VI.

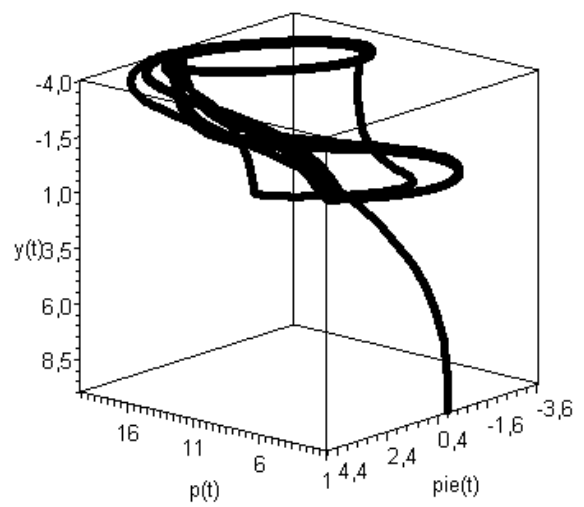

Lyapunov exponents have the following values $0.0635,0,-0.0005,-1.7475$. Lyapunov dimension has a value 3.

\section{Conclusions}

The four-equatio.n model was formulated in this paper. This model is actually augmented Kaldor model which is not only very well known but is intensively studied in dynamic economics. The original Kaldor model had been created by the equations (17) and (18). We have used a non-linear investment function that is the product of the production and the propensity to invest. The logistic function was chosen for an approximation of the propensity to invest. Another type of non-linearity in our model is the non-linearity used in a velocity of money. The velocity of money is defined in our approach by the non-linear function of expected inflation. The logistic function as a realistic approximation of the velocity of money was chosen as well. By simulations of 
numerical examples this augmented Kaldor model has demonstrated more complex behaviour of the simple closed economic system. The values of Lyapunov coefficient demonstrate a chaotic behavior of this model in spite of its simplicity.

\section{References}

[1] ALLEN, R. D. G. (1967). Macro-Economics. London : Macmillan, 1967.

[2] FLASCHEL, P.; FRANKE, R.; SEMMLER, W. (1977). Dynamic Macroeconomics. Cambridge, MIT Press, 1997.

[3] GUCKENHEIMER, J.; HOLMES, P. (1986). Non-Linear Oscillation, Dynamical Systems and Bifurcations of Vector Fields. Berlin, Springer Verlag, 1986.

[4] KODERA, J. (2002). Four Equation Model of Price Dynamics. In Ramík, J. (ed.). Proceedings of the $20^{\text {th }}$ International Conference - Mathematical Methods in Economics 2002. Ostrava : VŠB-TU, Ostrava 2002, pp. 151-155.

[5] KODERA, J.; SLADKÝ, K.; VOŠVRDA M. (2003a).: The Extended KaleckiKaldor Model Revisited. In Proceedings of the $21^{\text {st }}$ International Conference Mathematical Methods in Economics 2004. Prague : University of Agriculture, 2003.

[6] KODERA. J.; SLADKÝ, K.; VOŠVRDA, M. (2003b). The Role of Inflation Rate on the Dynamics of an Extended Kaldor Model. In Second Workshop of the Society for Computational Economics: Special Interest Group on Economic Dynamics, Complex Behavior in Economics: Modeling, Computing, and Mastering Complexity "Complexity 2003". Aix en Provence, Society for Computational Economics, 2003.

[7] LORENZ, H.-W. (1994). Nonlinear Dynamical Economics and Chaotic Motion. Berlin : Springer Verlag, 1994.

[8] MEDIO, A. (1993). Chaotic Dynamics. Theory and Applications. Cambridge : Cambridge University Press, 1993.

[9] TAKAYAMA, A. (1994). Analytical Methods in Economics. Hertfordshire : Harvester Wheatsheaf, 1994.

[10] TOBIN, J. (1975): Keynesian Models of Recession and Repression. American Economic Reviews, 1975, vol. 65, no. 2, pp. 195-202. 


\title{
Výroba, kapitál a dynamika cen ve světle Kaldorova modelu
}

\author{
Jan Kodera - Miloslav Vošvrda
}

\begin{abstract}
Abstrakt
Naším cílem je vytvořit dynamický spojitý model malé otevřené ekonomiky $\mathrm{s}$ jednoduchou strukturou a s minimálním počtem nelinearit, který by generoval aperiodické oscilace cen. Základ tohoto modelu je převzat $s$ tradičního dynamického Kaldorova modelu. Model je vytvořen čtyřmi diferenciálními rovnicemi popisující dynamiku produkce a kapitálu, vývoj cenové hladiny a vývoj očekávané inflace. Analýzu provádíme na numericky kalibrovaném modelu. Z hlediska složitosti je zajímavé řešení čtyř-rovnicového modelu, které vykazuje chaotické vlastnosti, což je indikováno kladným Ljapunovovým exponentem.
\end{abstract}

Klíčová slova: investiční funkce; míra investic; sklon k úsporám; očekávaná inflace; nelineární systém; Jacobián; vlastní čísla; Ljapunovi̊v exponent.

\section{Production, Capital Stock, and Price Level Dynamics in the Light of Kaldorian Model}

\begin{abstract}
The purpose of this paper is to study a price level dynamics in a simple fourequation model. A basis of this model is developed from dynamical Kaldorian model which could be noticed very frequently in works of non-linear economic dynamics. Our approach is traditional. The difference is observed in a choice of an investment function. The investment function depending on the difference of logarithm of production and logarithm of capital (logarithm of the productivity of capital) is in a form of the logistic function. These two equations create relatively closed sub-model generating both production and capital stock trajectories. Two other equations describe the price level dynamics as a consequence of money market disequilibrium and continuously adaptive expectation of inflation. Our investigation is firstly aimed to core model dynamics, i.e., a dynamics of the production and capital stock. Secondly is to analyze dynamics of the model as a whole, i.e., to the first part is superadded the price dynamics and expected inflation dynamics depending on both an adaptation parameter of the commodity market and a parameter of the expectation. Thirdly, we compute Lyapunov exponents for simple model of closed economy showing its chaotic behavior.
\end{abstract}

Key words: investment ratio; propensity to save; expected inflation; nonlinear system; price dynamics.

JEL classification: E44. 